\title{
Nanofiller/Natural Fiber Filled Polymer Hybrid Composite: A Review
}

\author{
Gbadeyan Oluwatoyin Joseph*, Sarp Adali, Glen Bright and Bruce Sithole
}

University of KwaZulu-Natal, South Africa

Received 6 April 2020; Accepted 24 October 2021

\begin{abstract}
In recent decades, the focus on the green composite speedily increases because they are low toxic, cheap, and available. A combination of naturally sourced polymetric polymer, suitable filler and excellent wettability and good filler/matrix interaction, synthesized with advance method and techniques appropriate to develop biocomposite with improved properties for different applications in marine, railway, construction and automobile industries. Although several naturally sourced material has been combined to achieve this aim, they're much agricultural waste that is underutilized. Nanocomposite shows acceptance for applications in different fields because the loading of small particles often of extensive surface material with captivating properties. It offers new technology and attracted opportunities for several sectors, such as MassTransit, automotive, aerospace, biotechnology, and nanotechnology industries. The combination nanofiller in natural fiber-filled composite enhances properties through the synergistic effect between the fiber and filler. This review provides information about various classes of natural fibers, nanofiller, based composite, nanocomposite, and natural fiber/nanofiller-based hybrid composite with specific concern to their applications. It also provides a summary of the emerging new aspects of milling techniques for synthesizing $\mathrm{CaCO}_{3}$ from snail shells and its application for developing hybrid composites for the sustainable and greener environment.
\end{abstract}

Keywords: Biocomposite, Snail shells, Natural fiber, Biopolymer, and Fillers

\section{Introduction}

The development of new materials with new required properties for a specific application by the process of combining different materials known as composite is becoming more attractive. This composite materials attractiveness is because composite is not found in nature directly, but formed through engineering [1-3]. Final product developed from the combination of two or more material constituents with different properties often results in a lightweight structure having superior stiffness and tailored properties for a specific application, where saving weight, better strength, and reduced energy are required [4]. It is well known that the two main components of composite are matrix and fiber/filler, fiber/filler serves as a reinforcement and matrix serve as a binder that bond fibers together to form a composite. Matrix imparts rigidity to composite, which aid reinforcement strength for supporting high tensile loads $[5,6]$. In the composite system, fiber often serves as load-carrying mechanisms that make application of stress on composite most times results in the transfer of loads from one fiber to another, glued together in a matrix. Matrix stiffness commonly goes together with brittleness; however, the combination of matrix and fiber produce a final composite with superior properties for specific applications. This composite may fail through different mechanisms, including but not limited to brittle cracking and extensive loading of fiber matrix. The limited amount of matrix at the fiber interface and fiber orientations may also be related to composite failure [7].
The introduction of organic or inorganic fillers to composite has been proved not only to provide solutions to the above-mentioned composite failure challenges but also to be an effective way to improve mechanical strength and stiffness of materials $[4,8,9]$. However, the effectiveness of filler loading on composite properties development often depends on the volume or percentage adopted [9]. Based on tremendous existing knowledge and experience derived from the characterization of synthetic fiber composite, the mechanical behavior of bio-composite has been studied. Naturally sourced fibers from plant and animal fiber composites have been widely investigated. Several kinds of research have provided information on mechanical properties such as impact, flexural, and tensile properties of plant fibers composite $[2-5,10]$. These plant fibers studied include but not limited to, sisal, hemp, jute, pineapple, and coir.

According to Brouwer [11], composite has been used far back in the ancient days. Beginning in about 3000 years ago, Egyptians combined straw and clay in composite systems to build walls. In this case, straw was used as reinforcement, while clay serves as both filler and matrix when water is introduced. The strength and stiffness offered by the final material result in fast development and usage of composite, which led to an increase in the production of synthetic composites in 1940 [12], which are still on till date. However, growing in the realization of the interconnectivity of global factors. These factors include but not limited to ecoefficiency; the principle of sustainability, green chemistry, industrial ecology, and engineering are being incorporated into the development of new materials, processes, and products for immediate and next generations [6, 12, 13]. 


\section{Biocomposites}

The stimulated awareness relating but not limited to the energy-intensive and unsustainable production processes of the reinforcing synthetic fibers and plastics triggered stringent policies to end the continued use of fiber reinforcement polymer (FRPs) in the EU [14, 15]. Furthermore, limited recyclability and end-of-life disposal options of FRPs raised several concerns. These concerns become barriers to the development of synthetic fiber-filled composite because of the catastrophic destruction they have on the ecosystem [6, 16]. The integrated policies of manufacturing composite provided composite science and genetic engineering processes with safe strategies to protect our environment. These policies offer significant opportunities for developing materials from biobased resources that support global sustainability [3, 4].

Composite materials, especially biocomposites from biofibers, bio-fillers, and bio-polymers, are considered to be one of the most suitable for the global sustainability shift. These bio-materials extracted from renewable agricultural and forestry feedstocks, including wood, agricultural waste, grasses, and natural plant fibers. The final biocomposite produced for the combination of these fibers/fillers has been used for several industrial products for durable goods applications. Biocomposite can be used alone, or combine with other material as a compliment. The exciting aspect of composite materials is that they can be tailored, modified, and designed to meet several application requirements (Fig. 1).

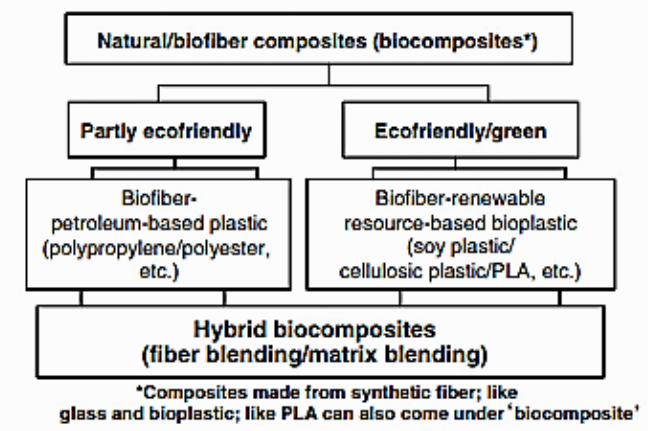

Fig. 1. Classification of bio-composite $[13,17]$.

Additionally, since natural fibers are recyclable, biodegradable, and cheap, biocomposite can be manufactured from a renewable source, which makes possible motivation for the development of non-toxic and environmentally friendly materials. This motivation surely will help in reducing environmental problems. The development of biocomposite has increased the high-tech revolution in recent decades, also served as a response to an increase in the quest for the development of recyclable, sustainable, and biobased materials. The combination of bio-based matrix and natural plant fibers has been proved to produce a low-cost composite that possesses the genetic properties of the constituents.

Material composed of natural/bio-filter or fibers and biobased resin is a viable alternative to fiberglass composite, predominantly in building, packaging, and automotive application. Likewise, food product industries draw more interest in using biobased material to reduce cancer. It has also become one of the fastest-growing additives for thermoplastic and thermosetting polymers [13, 18, 19]. Recent enhancements in bio-composite development have offered researchers opportunities to developed several biobased composites[10, 20-23]. Stiffness and strength of reinforced fibers and matrices suitable for the development of bio- composite have been studied extensively [20, 22, 24-30]. However, the incompatible nature of fibers hydrophilic and hydrophobic matrix combined harm fiber-matrix adhesion, which ultimately results in poor mechanical properties. Several investigations have been conducted to solve compatibility, wetting of this fiber by matrix, loading optimization, and critical length of the filler/fiber, which eventually have a potential effect on the strength and stiffness of final composite material [31-33].

Andersons et al.[34] investigated flax and thermoplastic matrix composites for determining the strength and stiffness of composite material under uniaxial tension. This study affirmed that relative fiber length determines the sensitivity of strength model to the matrix and adhesion properties. This discovery suggested that a more sophisticated strength model such as critical fiber length and loading optimization should be considered in the case. With this understanding, Awal et al. [35] developed biocomposite fiber from the combination of wood pulp and polypropylene (PP) using the extraction process.

The generated fiber was investigated to understand the nature of relations of wood pulp reinforcement with a polypropylene matrix. The results show fiber length lies between 0.2-1.0, which may be classified as critical length for the study. A favorable fiber-matrix adhesion and chemical linkage for improved strength were observed. This outcome is evidence that compatibility, critical length of the fiber, and fiber-matrix adhesion plays a significant role in the improvement of mechanical strength and stiffness of biocomposite.

\section{Applications of biocomposites}

Environmental sustainability, eco-friendly, green chemistry, and industrial ecology offered by natural composites, known as biocomposite, are controlling the manufacturing of nextgeneration materials, processes, and products [36]. Besides, the increase in global environmental, high percentage collapse of petroleum resources, and social concern brought biocomposite to the limelight. Similarly, innovative ecofriendly regulations have pushed for the search of new composites, which are compatible with the environment. In searching for suitable material, biocomposite found to be one of the most suitable. This discovery has drastically increased the use of biocomposite materials in different sectors over the past decades. These sectors include but not limited to the domestic sector, aerospace industries, circuit boards, mass transit, and automobile interior applications [37]. However, the usage of biocomposite products is limited in some other sectors due to low mechanical strength [36]. This challenge consequently generated several kinds of research on how to improve the mechanical strength of biocomposite [38-44].

In this regard, several types of natural fibers from different sources have been investigated. These fibers are incorporated into polymer matrices to fabricate composite materials that exhibit strength and stiffness that can contend with the mechanical properties of synthetic fiber-based composites. As a result of rigorous research for inexpensive and alternative fiber led to the discovery of agriculture waste such as plant leaf, back, and fiber composites. In this regard, Bharath et al.[37] confirmed that fiber extracted from agricultural wastes could be used to develop fiber-reinforced polymer composites for commercial use and have considerable market demand. The materials produced from the aforementioned natural-fiber-reinforced composites are 
Gbadeyan Oluwatoyin Joseph, Sarp Adali, Glen Bright and Bruce Sithole/

Journal of Engineering Science and Technology Review 14 (5) (2021) 61 - 74

one of the most promising sectors for part development in automotive, both for applications and tonnage, most especially structural automotive parts or engineered parts. This area is where many applications for non-woven products and compounds are utilized, and most technically advanced. Products engineered from these materials include package shelves, Class A parts, boot trim panels, window panel, as shown in Figure 2, under-the-hood parts, structural parts, and dashboards. The major challenge is to provide more information about these materials, their properties, their processing requirements, and potential applications.

Moreover, these biocomposite materials are only affordable but also reduce automobile net weight. Volvo car affirmed that usage of Bcom powerRids reinforced composite shown in Figure 2 could not only used in a wide range of semi-structural interior parts but instantaneously reduce up to $50 \%$ weight when related to current standard engineering plastics [45].

Michael Carus, Managing Director of the Nova-Institute from Hürth, Germany, one of the notable exhibitors specializing in biocomposites, acknowledged the positive projection at which this composite is developed and used for a variety of manufacturing application. According to him, in 2012, 350,000 tonnes of wood and natural fibers reinforced biocomposite products were produced by more than 100 companies in Europe. The majority of these products were manufactured from wood flour and wood fibers (wood-plastic composite) using extrusion techniques. European automobile manufacturers used over 90,000 tonnes of these natural fiber composite. As of 2014, both wood-plastic (WPC) and natural fibers biocomposites (NFC) shares stretch to above15\% of the total composites market [48].
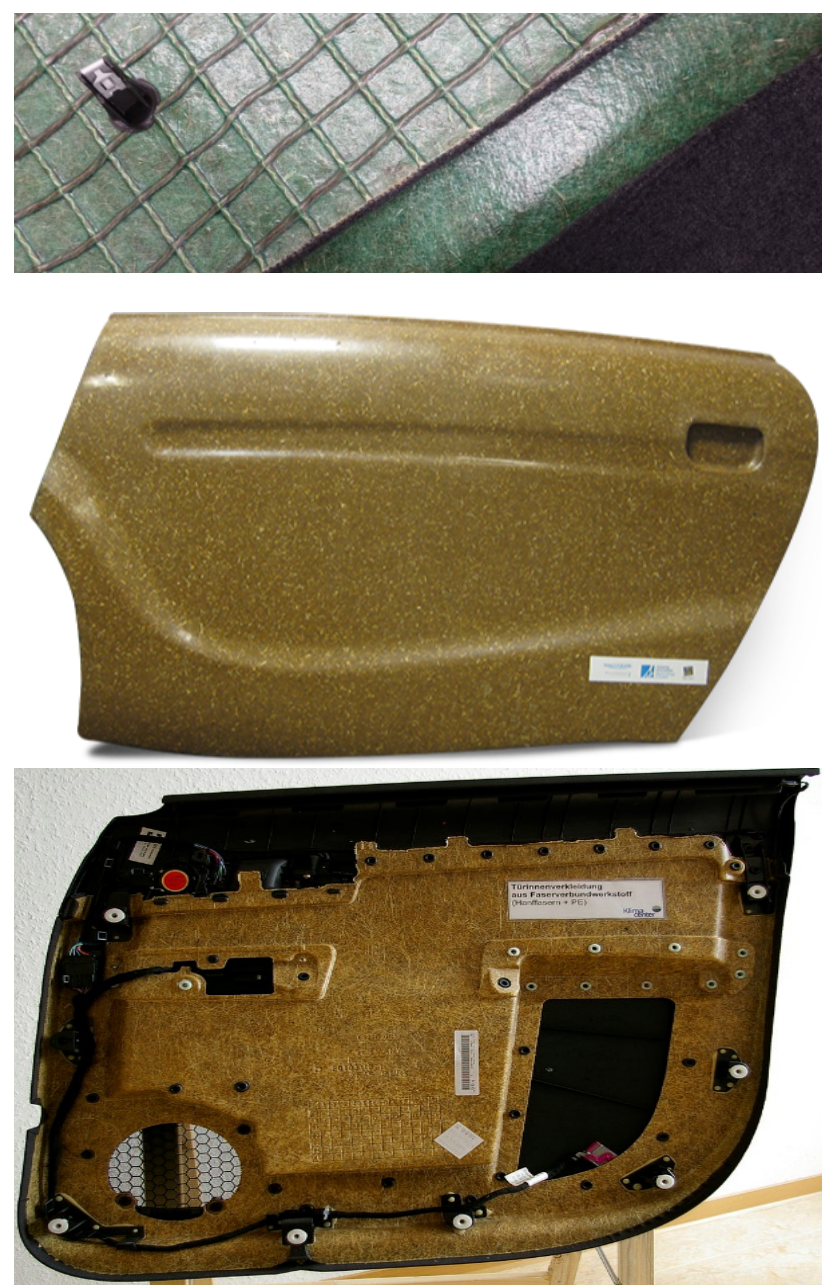

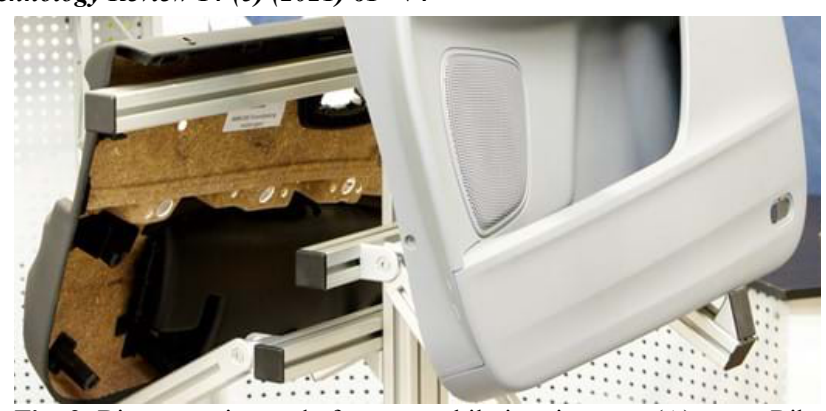

Fig. 2. Biocomposite made for automobile interior part: (A) powerRibs reinforcing automotive interior parts in Volvo Cars [45] (B) Window panel [46] (C) Interior carpeting [47] and (C) Door [48].

A review conducted by Amar et al. [13] confirmed that the production of materials and chemicals from biobased feedstock is estimated to rise from $15 \% \sim 18 \%$ in 2020 , and $\sim 25 \%$ in 2030 . Anticipations are that renewable resources could be the base materials for two-thirds of the $\$ 1.5$ trillion global chemical industry production. Due to this, the United States forestry, agricultural, chemical communities, and life sciences established tactical visions for using plants and agricultural remains for the production of industrial products, and also identified the main barriers that may be encountered during implementation. Technology measures such as Road Map for Plant/Crop-based Renewable Resources 2020, established by the U.S. Department of Agriculture (USDA), as well as the U.S. Department of Energy (DOE), was put in place to target $10 \%$ of basic chemical building blocks ascending from plant-derived renewables by 2020. Through these ideas, they plan to achieve more growth, targeting up to $50 \%$ by 2050 [13]. This idea provides more information about how the natural fiber market is growing. It is also evident that the development of natural fibers reinforced biocomposite products is becoming an effective way to improve the economy. These facts are eventually the drive and motivation behind the development of hybrid nano-shell biocomposite widely. Since biocomposite is the combination of matrix and natural fiber, it is imperative to review the sources and composition of natural fiber.

\section{Natural fibers}

Natural plant fibers are made up of lignin and cellulose, protein, and vegetable oil, as well as carbohydrates such as sugars and starch. These constituents are often used for producing new materials and chemical products [16]. Furthermore, these green materials possess environmental benefits with various types of cellulose and fibers suitable for the development of reinforced composite [49-55]. According to Joshi et al. [14], natural fiber-based composites are mostly expected to be environmentally friendly than synthetic fiberbased composites in most cases due to the following reasons: (i) Manufacturing of natural fiber often has lower environmental impacts than glass fiber production; (ii) higher fiber loading of natural fiber, which equivalent to performance, reduces the amount of more polluting base polymer composite; (iii) the usage of light-weight natural fiber composites, particularly in automobile industries helps in fuel efficiency and reduces emissions in the use phase of the component, [15]; and (iv) end of life disposal of natural fibers, consequently, results in improved energy and carbon acknowledgments [56, 57]. 


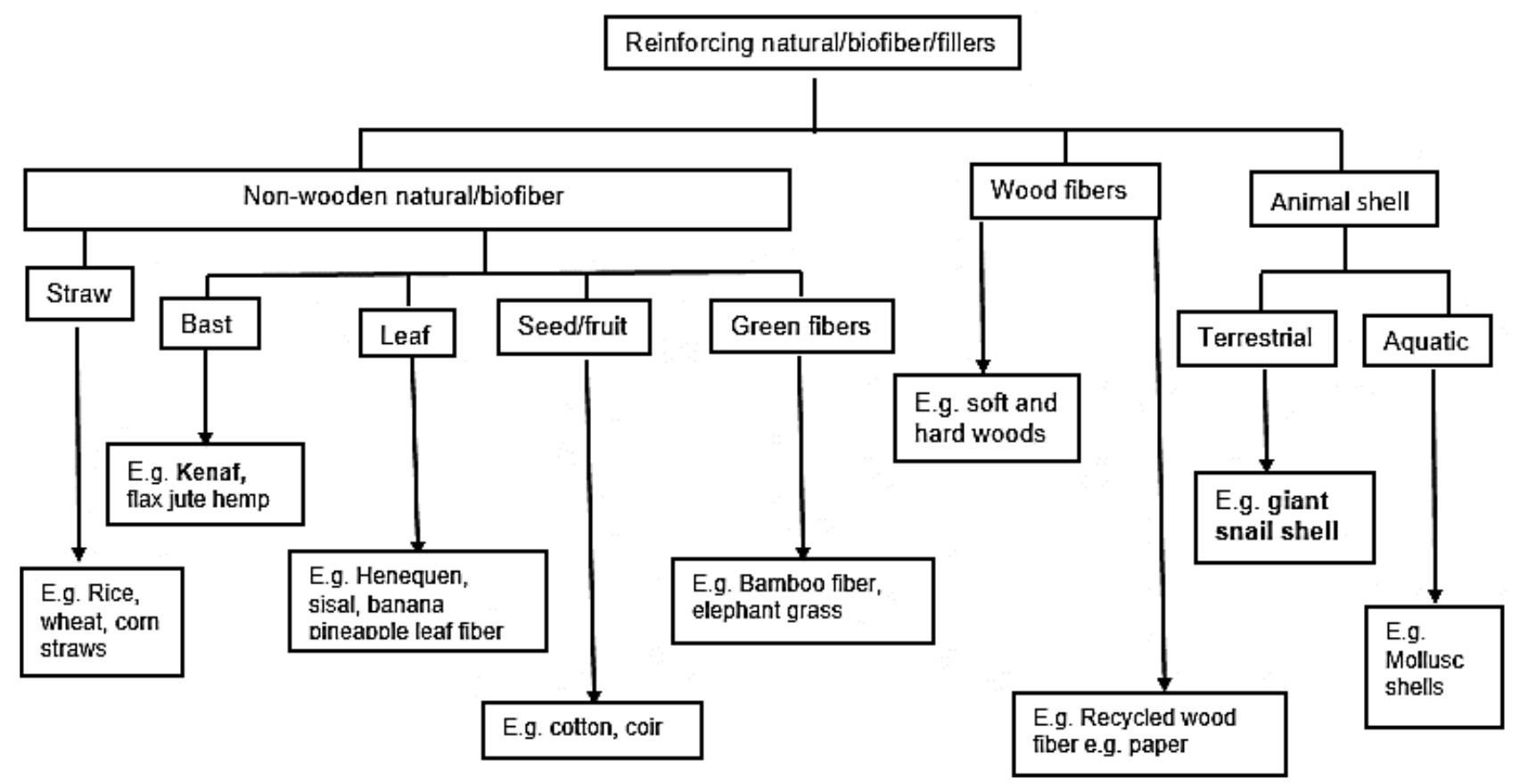

Fig. 3. Modified schematic classification of natural fibers [13].

Furthermore, advantages of natural fibers include but not limited to excellent acoustic insulation characteristics, high biodegradability, low $\mathrm{CO} 2$ emissions, and exceptional specific modulus. On average, natural fibers are cheaper compared to synthetic fibers. In fact, the price of natural fibers depends on the functionality of the fiber type [58]. Meyers et al. [59] established that natural (or biological) materials are complex composites having outstanding mechanical properties when considering the weaker components, from which they are assembled.

The complex structures formation of natural fiber becomes an inspiring material component for Researchers in the designing of novel materials. However, natural fiber has a drawback, which includes but not limited to high moisture, low modulus, disintegration in a biological attack, or alkaline, absorption, and inconsistent physical and mechanical properties. One of the identified solutions to all these difficulties is the chemical treatment of the fiber $[60,61]$. The chemical treatment is deliberated in the subsequent section.

\subsection{Classification and Structure of natural fibers}

It is well known that there are several kinds of natural fibers. In this regard, natural fiber is classified into sub-groups for a better understanding of their nature, origin, and sub-group. Naturally sourced fibers are categorized into two main groups in harmony to their background, which are plant and animal fibers. Animal fibers either come from animal hair, for example, wool fibers; are produced by silkworms, or extracted from bird feathers (Fig. 3).

Moreover, nanofiller of a different particle could be produced from mollusk and terrestrial snail shells, bones, and horns. Plant fibers can be divided into sub-groups: 1) wood fibers and 2) crop fibers, which are made of seed fibers such as cotton or kapok. Bast fibers such as hemp, flax, hemp, ramie, and jute; leaf fibers such as sisal and pineapple; stalk fibers such as bamboo, banana, and alpaca; or fruit fibers such as coir [62]. Although animal fibers consist of proteins, plant fibers are comprising of cellulose fibrils exhibiting a very high tensile strength that is embedded in the hemicellulose and lignin matrix.

Likewise, natural fibers, both animals and plant fibers, composed of parts that may be used as a reinforcement for composite development [63-65]. However, a plant fiber with cellulose is stiffer and more substantial compared to animal fiber. Therefore, plant fiber or a combination of both, where animal fiber serves as filler, may have a strong structure suitable for the development of biocomposite. Given this, this suggests the combination of both fibers. A combination of cellulose fibrils glued together by lignin and hemicellulose known as biofibers and snail shells at nanoparticle sizes could be a functional research area to explore.

Plants or weed natural fibers consist of lignin, cellulose, hemicellulose, waxes, and pectin [66-68]. As shown in Figure 4 , the microstructure of natural fiber is encompassing with different hierarchical structures, and this single fiber has a diameter of about 10-20 $\mu \mathrm{m}$, comprises of four concentric layers includes primary, outer secondary, middle secondary, and inner secondary walls. Lignin is a nature prevailing sweet-smelling polymer found in most land-dwelling plants at approximately amount ranges from 15 to $40 \%$ dry weight. It is the main element of vascular plants and polysaccharides in nature [69]. Lignins often play significant roles in the formation of the projectile of cell walls, particularly in bark and wood, because of the transfers of rigidity. The structure of the lignin is exceptionally complex as monolignols are linked through several connections into a three-dimensional network. It has constituents of a very high molecular mass of copolymer of aromatic and aliphatic. Pectin, functioning as a binder to hold fiber together, exhibiting a polysaccharide nature like cellulose and hemicellulose [70,71]. Chemically, lignin is a cross-linked phenolic polymer with stable thermal behavior $[69,72]$. The chemical complexity of this polymer provides woody plants and trees structural integrity. 


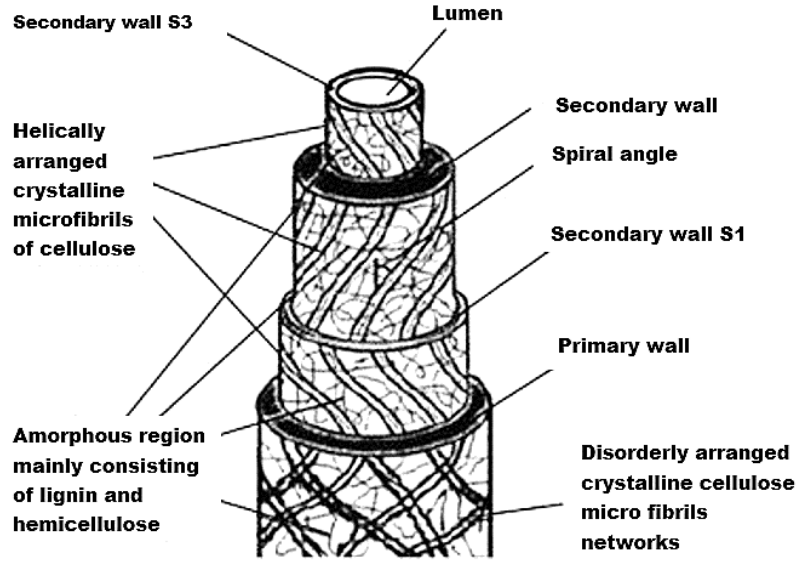

Fig. 4. Structural component of a biofiber [71, 73].

Furthermore, the distribution of lignin between hemicellulose and cellulose, provide binding and stiffening of plant fibers that may be related to the mechanical strength exhibited by plant fiber. Ragauskas et al. [74], confirmed that most large-scale industrial procedures make use of plant polysaccharides techniques by burning lignin to produce the necessary power for converting biomass efficiently.

Cellulose is the essential constituent of hard cell walls that border plant cells create plant leaves, stems, and branches more durable. As the most substantial skeletal component, it possesses inexhaustible polymeric raw material with captivating structure and properties. This structure made cellulose regarded as the most abundant natural polymer found in the plant, some bacterial and green algae. Cellulose is a linear sequence of ringed glucose with a flat ribbon-like conformation. Cellulose is a green polymeric material containing 1,4- $\beta$-D- anhydroglucose (C6H11O5) reiterating units merged by 1,4- $\beta$-D-glycosidic connections at $\mathrm{C} 1$ and $\mathrm{C} 4$ position, and every single unit includes three different hydroxyl collections as shown in Figure 5 [71, 75, 76].

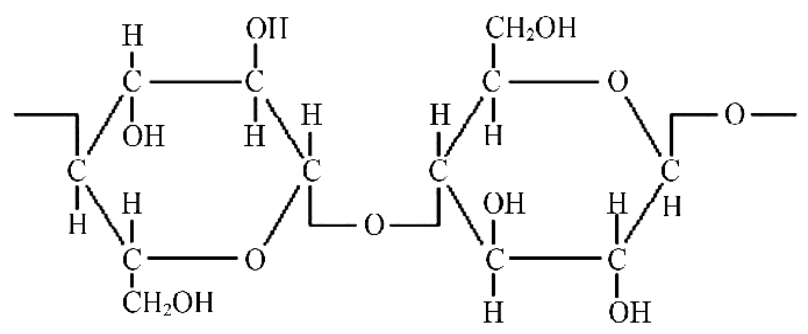

Cellulose

Fig. 5. Schematic diagram of the cellulose structure [77].

It possesses desirable high molecular weight with a polymer that can be defined as renewable, biodegradable, and natural.

Furthermore, cellulose possesses high specific strength and stiffness, and biodegradability is a looked-for fiber ratio and readily available from the natural source. The discovery and knowledge of cellulose chemistry and structure have led to the development of several innovative techniques and materials [78]. However, natural fiber has drawbacks include but not limited to water absorption, interfacial bonding, and material degradation. Therefore, the next section discussed how these drawbacks affect natural fiber in the composite.
4.2. Challenges of natural fibers usage in composite applications

Despite huge advantages of natural fiber, they still face challenges such as low modulus, disintegration in alkaline, or a biological attack, high moisture absorption, and unevenness in physical and mechanical properties when compared with standard engineered material or synthetic fibers [71, 79]. Furthermore, Ho et al. [79] confirmed that poor wettability reduces adhesion and degradation at the fiber/matrix interface. These deteriorate fiber during the manufacturing processes, which are the main courses of biocomposite failure. Similarly, a review conducted by Pickering et al. [80] stated that one of the main factors affecting the mechanical performance of natural fiber includes but not limited to fiber selection. This selection is in terms of types, harvested time, extraction method, aspect ratio, fiber treatment, fiber content, and orientation. These factors make selecting quality fiber challenge. Nevertheless, banana is a perennial plant that replaces itself.

Besides, bananas do not grow from a seed but a bulb or rhizome, and it takes 9 to 12 months from sowing a banana bulb to harvesting the fruit, which depicts surplus available of the fiber [81]. Furthermore, Banana fiber knowns as lignocellulosic fiber obtained from the pseudo-stem of banana plant (Musa sepientum) is a bast fiber with relatively good mechanical properties. Consequently, numerous studies have suggested that banana fiber is a suitable reinforcement for improving mechanical strength composite materials [82-85]. The characteristics above of natural fiber often lead to fibermatrix compatibility reduction, which affects surface bonding and, therefore, compromises the performance of the overall composite. Because of these limitations, this study constrains the application of natural fiber biocomposite to the internal mechanisms of train and automobile vehicles.

\subsection{Moisture absorption in fibers}

The moisture immersion rate of natural fiber has been identified as one of the factors that reduce the mechanical strength of plants fiber-filled biocomposite [49, 86-88]. This discovery led to a rigorous investigation on how to mitigating the water intakes and increase the interfacial bonding of the natural fiber and matrix so that mechanical properties could be improved [89-93]. Van de et al. [93] enhanced the adhesion and interfacial bonding of UD flax fiber-filled composite using an alkaline fiber chemical treatment after weak interfacing bonding of UD flax fiber was identified. Results show that the treated fiber exhibited a higher mechanical property compared to non-treated.

In the same manner, Anbukarasi and Kalaiselvam [94] experimentally investigated the influence of fiber volume loading $\left(0.3-0.5 V_{f}\right)$, dimension, and alkaline treatment of fibers on mechanical, thermal, and water absorption behavior of luffa reinforced epoxy composites. The naturally available luffa fiber mat shaped were fabricated in three different mediums, which are short fibers, and mat shaped fibers were processed and used to developed fiber reinforced epoxy composite. Results gathered from this study showed that 0.4 $V_{f}$ treated mat fiber-reinforced composite exhibited higher tensile, flexural, compressive, and impacted the strength of $13.7 \%, 6 \%, 72.43 \%$, and $163.6 \%$ respectively than untreated fiber-reinforced composites.

The improvement in mechanical properties observed was related to the homogeneous dispersion of fibers in epoxy polymer and good interfacial bonding. These two studies show that if a reinforcement does no merged with the matrix, it does not add any value in terms of strength improvement. 
Gbadeyan Oluwatoyin Joseph, Sarp Adali, Glen Bright and Bruce Sithole/

Journal of Engineering Science and Technology Review 14 (5) (2021) 61 - 74

Subsequently, fiber treatment was adopted to acquire efficient hydrophobic hurdles and required interfacial bonding with the matrix that enhances the bond of biofiber and polymeric material. According to $\mathrm{Li}$ et al. [95], chemical treatment of fiber help in improving the adhesion between the fiber surface and the polymer matrix. Undertaking this may not only modify the fiber surface but also increase fiber strength. Therefore, the next section discussed different chemical treatments giving to biofiber.

\subsection{Fiber treatment}

The improvement of mechanical strength for natural fiberfilled composite depends on the interaction and bonding force acting between the reinforcement and matrix. This fact has inspired researchers to consider several steps for enhancing fiber and matrix surface bonding ability. Amongst numerous techniques that have been implemented in the past, giving chemical treatment has found to be one of the most effective ways of improving the surface property of the fibers (reinforcement) [96-104]. Ho et al. [79] argued that the properties of natural fiber-filled polymer composite are principally ruled by the pre-treatment of fiber and manufacturing process adopted for composite fabrication. Given this, different chemical treatment has been suggested; these include but not limited to alkali, silane, and acetic anhydride treatments; however, alkali treatment is commonly used.

Each of these chemical treatments has different or own effect on the reinforcement, which often influence mechanical properties. According to Sunija et al.,[105] silane treatment is a giving chemical treatment for improving the surface property of reinforcement, which helps in enhances the mechanical strength of natural fiber-based composite [106]. Similarly, Haque et al. [107] confirmed that acetic anhydride treatment is one of the ways of enhancing surface bonding capacity of natural fiber-matrix in a composite as improvement in thermal and mechanical properties were achieved using this technique.

Amongst several chemical treatments suggested from the steps taken by scientists, alkali-treated of fiber using sodium hydroxide solution has been identified to be most effective. The investigation results stated that giving alkali treatment to natural fiber has a significant effect on the enhancement of the surface adhesion ability of the fiber and matrix. [100, 104].
Goda et al. [96] studied the influence of load application through the mercerization of natural fiber using ramie fibers as a case study. This load technique application was employed to improve the mechanical properties of the fiber. Before this investigation, fibers were alkali-treated by $15 \%$ of sodium hydroxide $(\mathrm{NaOH})$ solution and was subjected to a load of 0.049 and 0.098 afterward.

The results reported proved that chemical treatment improved fiber tensile strength up to $18 \%$, and fracture strain drastically increased from 0.045 to 0.072 compared to untreated fiber. A notable decrease in Young modulus of treated fiber was also observed. The improvement in strength and fracture strain upon mercerization was related to change in morphological and chemical structures in microfibrils of the fiber. Furthermore, Meon et al. and Edeerozey et al. [97, 98] soaked kenaf fiber with $3 \%, 6 \%$, and $9 \%$ of sodium hydroxide $(\mathrm{NaOH})$ solution to investigate the optimum concentration of chemical required for fiber treatment. The fiber was soaked for a day and dried for 24 hours before testing. They discovered a significant improvement in mechanical properties of treated fiber at an optimum level of $6 \%$ as compared to untreated and another sample treated with $3 \%$ and $9 \% \mathrm{NaOH}$.

Similarly, Paul et al. investigated the effect of fiber loading and chemical treatment on the thermophysical properties of the banana fiber-filled composite. An alkaline chemical treatment was giving to banana fiber using different concentrations of $2 \%$ and $10 \%$ of sodium hydroxide $(\mathrm{NaOH})$ solution. The experimental results show that $10 \%$ of sodium hydroxide treated banana fiber composite exhibited superior thermophysical properties than $2 \% \mathrm{NaOH}$ treated banana fiber composite. This result suggested that chemical properties have a positive effect on natural fiber, and it shall be adopted in this present study.

\subsection{Properties of natural fibers}

Natural plant fibers possess specific high mechanical strength and stiffness; however, lower when compared to synthetic fiber [94]. In Table 1, it is clearly shown that natural fiber has comparable properties such as elongation at break, stiffness, and density compared to that of synthetic fiber. These mechanical properties can be modified for different applications through proper selection of suitable fibers, matrices, additives, and fabrication methods.

Table 1: Comparison of mechanical properties for synthetic and natural reinforcing fiber [80, 82, 108-111].

\begin{tabular}{l|l|l|l|l}
\hline Fiber & $\begin{array}{l}\text { Tensile Strength } \\
\text { (MPa) }\end{array}$ & $\begin{array}{l}\text { Young's Modulus } \\
(\mathbf{G P a})\end{array}$ & $\begin{array}{l}\text { Elongation at Break } \\
\mathbf{( \% )}\end{array}$ & Density $\left(\mathbf{g} / \mathbf{c m}^{\mathbf{3}}\right)$ \\
\hline Synthetic & $2000-3500$ & 70 & 2.5 & \\
E-Glass & $3000-3150$ & $63.0-67.0$ & $3.3-3.7$ & $2.5-2.59$ \\
Aramid & 4000 & $230.0-240.0$ & $1.4-1.8$ & 1.4 \\
Carbon & $140-800$ & $11-32$ & $2.5-3.7$ & 1.4 \\
Natural & $529-914$ & $27-32$ & 3 & $0.6-1.1$ \\
Bamboo & $200-800$ & $8-78$ & $1.5-1.8$ & $1.31-1.33$ \\
Banana & $223-930$ & $14.5-53$ & $1.5-2.7$ & $1.3-1.49$ \\
Jute & $345-2000$ & $27.6-103$ & $1.2-3.3$ & 1.4 \\
Kenaf & $365-700$ & $9.0-38$ & $2.0-7.0$ & $1.4-1.5$ \\
Flax & $270-900$ & $23.5-90$ & $1.0-3.5$ & $1.33-1.5$ \\
Sisal & $95-230$ & $2.8-6$ & $15-51.4$ & $1.4-1.5$ \\
Hemp & $1.0-1.55$ & $400-1000$ & $24.5-128$ & $1.15-1.46$ \\
Coir & Ramie & & & $1.0-1.55$ \\
\hline
\end{tabular}

Consequently, this provides fibrous material suitable as a replacement or to serve as an alternative to synthetic fiber
[79]. Significantly, Banana fiber exhibit a comparable stiffness, elongation at break, and density with E-glass fiber 
shown in Table 1 and confirmed its suitable replacement. Moreover, a modified or treated plant fiber with coupling agents often have functional linkage with matrix, which eventually improve composite mechanical strength [112]. The core importance of plant fiber is low cost and density, combined with a renewable matrix to produce a biobased (greener) and lightweight composite with improved strength and stiffness [112-114].

\subsection{Banana fibers}

Bananas are one of the world's most pleasing fruit. It is cultivated and consumed in over 150 countries, with over 105 million tonnes of fruit produced annually. Asia and America are leading producers of banana, accounting $57 \%$, and $26 \%$ of total annual production, respectively, and Ecuador is the largest exporter of banana fruits in the world. [115-117]. Bananas are said to be native to tropical South and Southeast Asia. They are among the most important commercial subtropical fruits grown in South Africa. Besides, they are planted for sale in local markets or self-consumption, and a little fraction of banana produced in South Africa is exported to the global market.

Bananas are produced mainly in Mpumalanga, Limpopo, and North and South Coasts of Kwazulu Natal [118]. Over 450,000 tons of banana was produced in South Africa in year 2013/14, and Kwazulu Natal has the major growing area of accounting for $15 \%(1700 \mathrm{Ha})$ of the total banana plantation area.

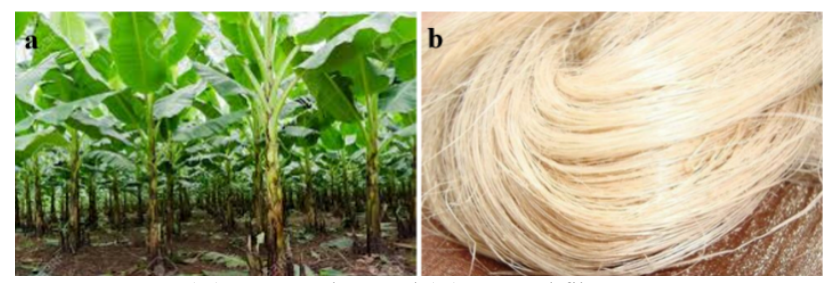

Fig. 6. Banana (A) mature plant and (B) Erected fiber

Moreover, these bananas fruit are produced by several pieces of large herbaceous flowering plants in the genus Musa that grows in clusters hanging from the top of the plant. Significantly. The pseudostem of this plant can bear one bunch in its life, leaving behind a large number of agricultural residues (starchy and lignocellulosic biomass) [119]. There are records for banana fruit used for consumption in the world, but there is no record for the use of the agricultural residue. After harvesting the fruit by cutting down the tree, the banana plant stem (pseudo-stem) dies and produces a large number of agricultural residues that cause environmental pollution [120] [121].

Researchers have implemented different techniques of extracting valuable additives such as fiber, cellulose, and lignin from agricultural residues to increase the importance of banana plantation. These additives are extracted using different techniques including but not limited to chemical, mechanical, or biological methods. The extraction of banana fiber using biological retting, which yields more fiber bundles without causing harm to the environment, has commonly reported in many studies [122-125]. The typical mature banana plants and the banana fibers extracted from the plant stem using the biological procedure is as shown in Figure 6 . This fiber has found use in packing cloth, string, ship towing ropes, cordage, and wood-pulp paper making [126, 127].

Moreover, naturally sourced fiber has several advantages over synthetic fibers such as renewability, appropriate stiffness, low density, mechanical properties, and high disposable. These advantages attract more investigations into the development of composite and biocomposite. However, achieving improvement in the properties of banana fiberfilled composite most times depends on the fiber length and content incorporated. Therefore, the next section discusses the effect of distance and content of banana fiber on composite or biocomposite.

\subsubsection{The effect of length and content of banana fiber on composite}

The lignocellulosic fiber extracted from banana pseudostem has proved to be a useful reinforcement in both thermoplastic and thermoset matrices [83, 128, 129]. They commonly used as chopped strands incorporated to enhance the strength of polymeric materials. The critical length and contents of fiber are essential factors in determining the effect of the loadbearing capacity of composite.

According to Mohan and kanny, fiber will not effectively bear the composite load when fiber length incorporated is lesser or greater than a critical length [130]. Based on this fact, they studied the effect of fiber critical length on the mechanical properties of composite material. Composite was prepared with fiber loading ranging from $30 \%$ fiber loading and fiber length ranging from $30 \mathrm{~mm}$ to $45 \mathrm{~mm}$. It was observed that composite filled with a fiber length of $35 \mathrm{~mm}$ offered better properties, although the fiber was infused with nanoclay. Paul et al. [71] also synthesized and characterized a biocomposite derived from the banana plant stem. The biocomposites were prepared with fiber loading ranging from $20 \%$ to $50 \%$. The results showed improved mechanical and thermal properties were at $30 \%$ loading.

Moreover, Boopalani et al. and Pothani et al. [131-133] argued that improvement in the properties of chopped banana reinforced composite solely depends on the fiber critical length and volume of loading. In this regard, Laly et at.[134], investigated the effect of fiber length and content on the mechanical properties of short banana fiber reinforced polyester composite. It was discovered that superior tensile strength was observed at $30 \mathrm{~mm}$ fiber length, while impact strength gave the maximum value for $40 \mathrm{~mm}$ fiber length. Similarly, $40 \%$ loading of fiber exhibited higher mechanical properties. Based on the information provided above it could be concluded that loading of banana fiber with length range from $30 \mathrm{~mm}$ and $40 \mathrm{~mm}$ at $40 \%$ loading is an effective way of enhancing composite mechanical properties. Besides, there is limited available literature reported on the incorporation of biobased nanofiller and banana fiber-filled thermoset polymer hybrid biocomposite. This study suggests that these challenges may be overwhelmed by reducing loading percentages of banana fiber, introduce biobased nanoparticle and thermosetting polymer, since the information provided in the available literature proved that percentage loading optimization of banana fiber not yet attained as there no uniform effect percentage of banana loading on composite material. The author may report that composite with $30 \%$ banana fiber exhibited superior mechanical properties in one study and another study maybe $40 \%$ loading. Thus, this review suggests the development of hybrid nano-shell plantfiber biocomposite, where biobased nanofiller could use as reinforced. This idea may reduce the quantity of banana fiber incorporated with less different loading percentages of nanocalcium carbonate synthesized from a snail shell or another naturally sourced filler material. However, the suitability of reinforcement filled needs to be investigated before the filler could be recommended for use. Therefore the next section 
discusses different sources, classification and uses of filler material, and their role in improving composite material when incorporated.

\subsection{Fillers}

Fillers, both organic or inorganic, play significant roles in improving specific characteristics of polymeric material [135138]. They may be incorporated to increase strength, conductivity, and thermal stability or resistance to indentation. Dittanet and Pearson [139] argued that filler or fillers are not only used to improve thermal, physical, chemical but also used to improve the bonding systems of composite favorable for enhancing mechanical properties. Loading of this filler may improve one property and negatively affect another in some cases. Most times, they are used to reduce the cost of expensive polymetric matrix and binders, which eventually reduces the cost of production [4, $9,140-142]$. Several filters have been employed to serve as reinforcement in polymer composites. Despite several fillers identified with potential for composite reinforcement, $\mathrm{SiO}_{2}$, $\mathrm{TiO}_{2}$, and carbon-based fillers such as carbon nanotubes and graphite nanopowder, calcium carbonate $\left(\mathrm{CaCO}_{3}\right)$ found most suitable and commonly used [142-145].

Amongst the fillers, as mentioned earlier, fillers with a high concentration of calcium carbonate $\left(\mathrm{CaCO}_{3}\right)$ is extensively used owing to their accessibility, advantageous mechanical strength, thermal stability, and biodegradability [146]. This discovery led to a rigorous investigation on calcium carbonate-based filler, and consequently, montmorillonite and kaolinite referred to as nanoclay was found to be most suitable [147, 148]. Studies conducted confirmed the effectiveness of nanoclay in improving several composite properties [135, 149]. However, it has been discovered that the end-life of nanoclays has adverse effects on human health and, at times, expensive when compared to naturally sourced fillers [138]. This fact consequently reduced the usage of this filler-besides, Marrot et al.[150], claimed that the negative impact of synthetic thermoset polymer and fiber on the environment could be reduced in two ways. First, by replacing synthetic fiber with natural fibers and secondly by replacing the petrochemical component in the matrix with biobased renewable equivalents. This clue rigorously increase studies towards the development of green composite using biobased ingredients.

Composite materials, especially biodegradable composites from bio-fibers, bio-fillers, and bio-polymers, are well fit into this global sustainability shift. These biodegradable materials extracted from renewable sources such as agricultural waste and forestry feedstocks, including wood, agricultural waste, grasses, and natural plant fibers have been used for numerous materials for durable goods application. This awareness inspired a scientist to source for a natural constituent that meets societal needs and supports global sustainability. Subsequently, in recent decades, natural fillers extracted from wood, hair as well as the animal shell has been investigated for the enhancement of thermal stability, degradation, strength and physical properties of polymeric materials [19]. The search for this suitable material led to the discovery of eggshells.

It was identified as potential filler due to the higher content of calcium carbonate $\left(\sim 95 \% \mathrm{CaCO}_{3}\right)$ in this material [151-153], which was eventually used as an alternative to commercial $\mathrm{CaCO}_{3}$ mentioned above. Research has been done on mollusk shell, animal bone and eggshell material that have been investigated for $\mathrm{CaCO}_{3}$, and it was proved that these materials have adequate filler characteristics for different applications $[19,154]$. In this regard, African giant snail is selected as a reinforced filler, with the hope of having sufficient $\mathrm{CaCO}_{3}$ providing excellent inter-linking property, which helps in improving mechanical strength and moisture absorption properties. Several studies have demonstrated the addition of these biological materials, in microparticle size form, to polymeric materials, and this resulted in improved composite materials. Also, a combination of two or more of these naturally sourced materials has been developed to produce advance materials with desired properties [19, 63, 155]. However, there is dearth information on the fundamental properties of the materials that could be exploited for bio-composites development. This issue may be due to the size of the biological materials - shells, in particular, it does not have adequate size/space required to produce a standard specimen for the measurement of mechanical properties. Therefore, these shells are grand or mill to micro/nanoparticles and disperse in materials to develop composite.

There are different milling techniques used for small organic particle synthesis. A mechanochemical procedure such as hand grinding or ball-milling has been reported to have an influence on the structure and composition of materials, which bring about an opportunity for preparation and Over many decades, montmorillonite and kaolinite with a high concentration of $\mathrm{CaCO}_{3}$ are sourced and synthesized using different techniques. These fillers are sourced from rock and manufactured using either gas pressure blasting or explosion method $[147,148,156]$. Despite the availability of numerous milling techniques used for small organic particle synthesis, mechanochemical technology has found to be most effective and widely used for milling biobased filler materials such as shells, horns and bone [156, 157]. With clearly information on how to grind the aforementioned materials into small sizes, it is imperative to investigate availability and suitability of snail shells in particular. This information is provided in next section.

\subsection{Snail shell}

Snail shells are regarded as a discarded bio-shell waste of snail's remnants from seashore, restaurants, dermatology, and snail sellers. Shell is an outer skeleton or exoskeleton, which serves not only as crucial protection against the sun, against drying out and predators for both lands, intertidal marine and freshwater snail $[158,159]$. In particular, gastropod shell has constituted a serious degree of threat to the environment with little or no economic value as they are arbitrarily abandoned after consumption of the inner edible meat [159]. Barros et al. [160] confirmed that over 80,000 tons of mussel shells alone are disposed of as waste annually.
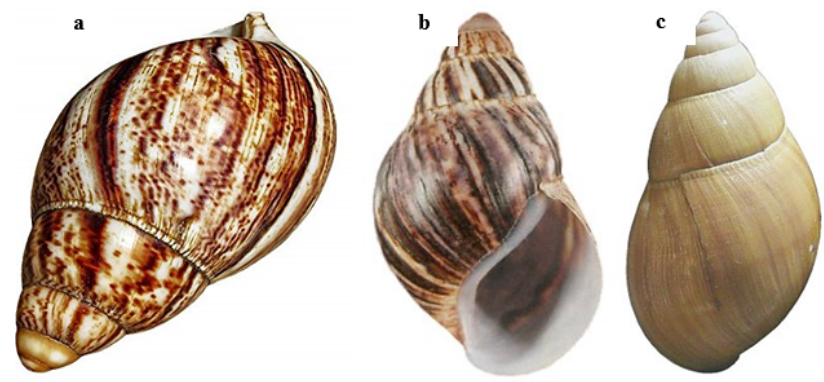

Fig. 7. Snail shell (a) Achatina Fulica (Giant Africa land snail), (b) Achatina Achatina, (c) Achatina Marginata.

Land snail shells are wasted in billions of tons every year. In particular, West African countries such as Nigeria, Ghana, Cote d'Ivoire, where snail meat is famous for consumption, disposes of shells as discarded. In Cote d'Ivoire, over 7.9 
Gbadeyan Oluwatoyin Joseph, Sarp Adali, Glen Bright and Bruce Sithole/

Journal of Engineering Science and Technology Review 14 (5) (2021) 61 - 74

million tons of snail meat are eaten annually. However, Ghana and Nigeria demand currently overtake snail meat supply, and the shells become a waste [161].

Consequently, farmers rear different land Snails species to meet local and foreign markets. The snail species are including but not limited to Achatina Fulica (Giant Africa land snail), Achatina Achatina, and Achatina Marginata, as shown in Figure 7. The main difference of this snail is size as Achatina Fulica is the biggest. Additionally, many commercial farms of land snail have been identified at Gauteng, cape town, South Africa, where millions of tons of snail are produced to meet the demands of snails meat [162, $163]$.

The IOL news reported that western Cape's snail farm produced more than 48,000 tons of land snail to meet France snail meat demands every year [163]. This only discussed the meat, but nothing has been said about the shell because they are regarded as unwanted. Despite considerable foreign and local demand of snail meats, the kind of commercial snail farms that operates in foreign countries such as Europe, and the United States, hardly exists in Africa [161], This implies that many tons of snails shells are wasted in those countries as well. This guarantee availability of land snail shell globally at no cost and also proof that the expected output of this research is sustainable. Additionally, usage of the shell regarded as waste presents a significant contribution to advancement of the economic importance of snail rearing farms.

Aside from the availability of shells, research has shown both freshwater and land snail shell have a high content of $\mathrm{CaCO}_{3}$, and the loading of shells at different particle sizes confirm as an effective way of improving some properties of polymer materials $[19,154]$. In this regard, Nwanenyi et al. [63] conducted an investigation on the effect of loading periwinkle shell at different particle sizes $(75 \mu \mathrm{m}, 125 \mu \mathrm{m}$, and $150 \mu \mathrm{m})$; filler content ( 0 to $30 \mathrm{wt} \%$.) and compatibilizer $(0.5$ to $2.5 \mathrm{wt} \%$ ) on mechanical properties of polyethylene. The mechanical properties explored on the shell particles and compatibilizer filled polyethylene include but not limited to tensile strength, elongation at break, tensile modulus, flexural strength, impact strength, and hardness. According to the experimental results, improvement in mechanical properties with a corresponding increase in filler loading was observed. This revealed reinforcement potential and effectiveness of loading $\mathrm{CaCO}_{3}$ synthesized from a snail shell for improving composite properties. Although there 60,000 species of terrestrial snail shells, however, many are underutilized as their basic properties are unknown. It is well known that filler and reinforcement are not complete without polymer, which serves as a binder in the composite. Therefore, the next section discussed matrix for biocomposite.

\section{Matrices in biocomposites}

Biocomposite is classified as a combination of natural fibers and synthetic binders or greener resin systems, which could be either thermosetting and thermoplastic polymer, and all of these classes could be used to developed biocomposite [71].

\section{Thermoset}

Thermoset can be referred to as irreversible polymer hardened by curing agent. This process is achieved by mixing a soft solid or viscous liquid prepolymer with a catalytic or hardener. Besides, thermoset liquid at room temperature allows easy loading of filler or fiber before the addition of the catalyst that makes cured or hardened. This mixing process often results in chemical reactions that create widespread cross-linking between polymer chains to create an infusible and insoluble polymer network. Most of the thermosetting polymer used in the composite industries is produced from petrochemical products.

Nevertheless, the growing demand for eco-friendly plastics increases the usage of the bio-based polymer for composite production [164, 165]. Several bio-based polymers such are cellulose plastics, polylactic acid, vegetable oil, and polyhydroxy alkonate have been extensively developed and commercialized [166, 167]. However, they are thermoplastic polymers,

In recent decades, several biobased thermoset polymers such as epoxy resin have been developed with some percentages of extracts from plants, linseed, soybean, Jatropha, and vegetable oil used for fabrication of biocomposite. This biobased resin is modified by the loading of either synthetic or naturally sourced fiber and fillers to fabricate green composite [185, 186]. Sandeep et al. [187] studied the mechanical behavior of green composite fabricated by incorporating agro-residues as soy stalk (SS), corn straw (CS), and wheat straw (WS) into the bacterial polyester, poly(3-hydroxybutyrate-co-3-hydroxy valerate). The effect of biomass fibers on the mechanical, thermal, and dynamic mechanical properties of poly(3-hydroxybutyrateco-3-hydroxyvalerate) was investigated. The loading of these biomass fibers significantly increased according to the result reported in this study.

\section{Conclusion}

The review conducted was on the development of biocomposite from different sources, including natural fibers and agricultural waste. It shows that natural fiber is becoming a material of choice for different applications in the industries include but not limited to mass transit, automobile, and aerospace. It also clear that despite vast research conducted on the discovery of natural materials for different applications, there still some natural material that needed to be sourced and investigated.

Although several kinds of research have been done on snails, however, limited information is available on the mechanical strength of their shells and how this could integrate to improve composite properties at nano-scales. Additionally, the reinforcement potential of banana fiber in the composite or hybrid composite systems is reviewed from different studies. However, it has been found that there is limited literature available on the development and characterization of biobased nanofiller and banana fiber reinforced biocomposite.

The review suggests the idea of using $\mathrm{CaCO}_{3}$, synthesized from wasted snail shells through mechanochemical techniques as a nanofiller in fiber-filled green matrix hybrid composite formation. A combination of these materials from natural sources may provide a biocomposite with comparable mechanical properties that could be used for development of original material for different applications in mass transit, marine, and automotive industries.

This is an Open Access article distributed under the terms of the Creative Commons Attribution License. 


\section{References}

1. S. Ismail and B. A. ABU, "A comparative study on the effects of paper sludge and kaolin on properties of polypropylene/ethylene propylene diene terpolymer composites," 2005.

2. N. S. Suharty, H. Ismail, K. Diharjo, D. S. Handayani, and M. Firdaus, "Effect of kenaf fiber as a reinforcement on the tensile, flexural strength and impact toughness properties of recycled polypropylene/halloysite composites," Procedia Chemistry, vol. 19 pp. 253-258, 2016.

3. Q. Zhang, Q. Liu, J. E. Mark, and I. Noda, "A novel biodegradable nanocomposite based on poly (3-hydroxybutyrate-co-3hydroxyhexanoate) and silylated kaolinite/silica core-shell nanoparticles," Applied Clay Science, vol. 46, no. 1, pp. 51-56, 2009/09/01/ 2009, doi: https://doi.org/10.1016/j.clay.2009.07.008.

4. D. N. Saheb and J. P. Jog, "Natural fiber polymer composites: A review," Advances in Polymer Technology, vol. 18, no. 4, pp. 351363, 1999, doi: doi:10.1002/(SICI)10982329(199924)18:4<351::AID-ADV6>3.0.CO;2-X.

5. N. Saba, M. Jawaid, O. Y. Alothman, and M. T. Paridah, "A review on dynamic mechanical properties of natural fibre reinforced polymer composites," Construction and Building Materials, vol. 106, pp. 149-159, 2016/03/01/ 2016, doi: https://doi.org/10.1016/j.conbuildmat.2015.12.075.

6. A. K. Mohanty, M. Misra, and L. T. Drzal, "Sustainable BioComposites from Renewable Resources: Opportunities and Challenges in the Green Materials World," Journal of Polymers and the Environment, journal article vol. 10, no. 1, pp. 19-26, April 01 2002, doi: 10.1023/a:1021013921916.

7. F. C. Campbell. "Structural Composite materials." https://www.asminternational.org/ (accessed 2018/08/30, 2018).

8. H. Tolonen and S.-G. Sjölind, "Effect of mineral fillers on properties of composite matrix material," Mechanics of Composite Materials, journal article vol. 31, no. 4, pp. 317-324, July 01 1996, doi: $10.1007 / \mathrm{bf00632618.}$

9. O. J. Gbadeyan, K. Kanny, and T. P. Mohan, "Influence of the multiwalled carbon nanotube and short carbon fibre composition on tribological properties of epoxy composites," Tribology - Materials, Surfaces \& Interfaces, vol. 11, no. 2, pp. 59-65, 2017/04/03 2017, doi: 10.1080/17515831.2017.1293763.

10. C. W. Chin and B. F. Yousif, "Potential of kenaf fibres as reinforcement for tribological applications," Wear, vol. 267, no. 9, pp. 1550-1557, 2009/09/09/ 2009, doi: https://doi.org/10.1016/j.wear.2009.06.002.

11. W. D. Brouwer, "Natural fibre composites in structural components: alternativeapplications for sisal?." Online.. Available: http://www.fao.org/docrep/004/Y1873E/y1873e0a.htm

12. T. P. and and B. Bensaude-Vincent. Composites Overview Online. Available:

https://authors.library.caltech.edu/5456/1/hrst.mit.edu/hrs/materials/ public/composites/Composites_Overview.htm

13. M. M. Amar K. Mohanty, Lawrence T. Drzal, Susan E. Selke, and a. G. H. Bruce R. Harte, Natural Fibers, Biopolymers, and Biocomposites: An Introduction 2005.

14. S. V. Joshi, L. T. Drzal, A. K. Mohanty, and S. Arora, "Are natural fiber composites environmentally superior to glass fiber reinforced composites?," Composites Part A: Applied Science and Manufacturing, vol. 35, no. 3, pp. 371-376, 2004/03/01/ 2004, doi: https://doi.org/10.1016/j.compositesa.2003.09.016.

15. J. Steger, "Light Weight! No Matter What the Costs? Plant Fibres for Light Weight Automotive Applications," Journal of Biobased Materials and Bioenergy, vol. 4, no. 2, pp. 181-184, // 2010, doi: 10.1166/jbmb.2010.1083

16. A. K. Mohanty, M. Misra, and G. Hinrichsen, "Biofibres, biodegradable polymers and biocomposites: An overview," Macromolecular Materials and Engineering, Review vol. 276-277, pp. $\quad 1-24, \quad 2000, \quad$ doi: $10.1002 /($ SICI)14392054(20000301)276:1<1::AID-MAME1>3.0.CO;2-W.

17. A. K. Mohanty, M. Misra, and L. Drzal, "Sustainable bio-composites from renewable resources: opportunities and challenges in the green materials world," Journal of Polymers and the Environment, vol. 10, no. 1-2, pp. 19-26, 2002.

18. H. Salam and Y. Dong, "Property evaluation and material characterization of soybean oil modified bioepoxy/clay nanocomposites for environmental sustainability," Materials Today Sustainability, vol. 5, p. 100012, 2019.
19. T. Mohan and K. Kanny, "Thermal, mechanical and physical properties of nanoegg shell particle-filled epoxy nanocomposites," Journal of Composite Materials, p. 0021998318773445, 2018.

20. L. K. Cardon, K. J. Ragaert, R. De Santis, and A. Gloria, "2 - Design and fabrication methods for biocomposites," in Biomedical Composites (Second Edition), L. Ambrosio Ed.: Woodhead Publishing, 2017, pp. 17-36.

21. M. Lewandowska-Szumieł and S. Rumiński, "14 - Cellular response to biocomposites," in Biomedical Composites (Second Edition), L. Ambrosio Ed.: Woodhead Publishing, 2017, pp. 335-356.

22. S. Ramakrishna and Z. M. Huang, "Biocomposites," in Reference Module in Materials Science and Materials Engineering: Elsevier, 2016.

23. S. S. Palayangoda and Q. P. Nguyen, "Thermal behavior of raw oil shale and its components," Oil shale, vol. 32, no. 2, p. 160, 2015.

24. I. D. Thompson, "5 - Biocomposites," in Biomaterials, Artificial Organs and Tissue Engineering, L. L. Hench and J. R. Jones Eds.: Woodhead Publishing, 2005, pp. 48-58.

25. H. P. S. Abdul Khalil et al., "15 - Mechanical properties of oil palm biocomposites enhanced with micro to nanobiofillers," in Biocomposites, M. Misra, J. K. Pandey, and A. K. Mohanty Eds.: Woodhead Publishing, 2015, pp. 401-435.

26. M. J. John and S. Thomas, "Biofibres and biocomposites," Carbohydrate Polymers, vol. 71, no. 3, pp. 343-364, 2008/02/08/ 2008, doi: https://doi.org/10.1016/j.carbpol.2007.05.040.

27. Y. Lu, L. Weng, and X. Cao, "Morphological, thermal and mechanical properties of ramie crystallites-reinforced plasticized starch biocomposites," Carbohydrate Polymers, vol. 63, no. 2, pp. 198-204, 2006/02/03/ 2006, doi: https://doi.org/10.1016/j.carbpol.2005.08.027.

28. S. O. Han, H. J. Ahn, and D. Cho, "Hygrothermal effect on henequen or silk fiber reinforced poly (butylene succinate) biocomposites," Composites Part B: Engineering, vol. 41, no. 6, pp. 491-497, 2010.

29. A. Alemdar and M. Sain, "Biocomposites from wheat straw nanofibers: Morphology, thermal and mechanical properties," Composites Science and Technology, vol. 68, no. 2, pp. 557-565, 2008/02/01/ 2008, https://doi.org/10.1016/j.compscitech.2007.05.044.

30. A. N. Nakagaito and H. Yano, "Novel high-strength biocomposites based on microfibrillated cellulose having nano-order-unit web-like network structure," Applied Physics A, journal article vol. 80, no. 1, pp. 155-159, January 01 2005, doi: 10.1007/s00339-003-2225-2.

31. A. Awal, G. Cescutti, S. B. Ghosh, and J. Müssig, "Interfacial studies of natural fibre/polypropylene composites using single fibre fragmentation test (SFFT)," Composites Part A: Applied Science and Manufacturing, vol. 42, no. 1, pp. 50-56, 2011/01/01/ 2011, doi: https://doi.org/10.1016/j.compositesa.2010.10.007.

32. K. Van de Velde and P. Kiekens, "Biopolymers: overview of several properties and consequences on their applications," Polymer Testing, vol. 21, no. 4, pp. 433-442, 2002/01/01/ 2002, doi: https://doi.org/10.1016/S0142-9418(01)00107-6.

33. A. Awal, M. Sain, and M. Chowdhury, "Preparation of cellulosebased nano-composite fibers by electrospinning and understanding the effect of processing parameters," Composites Part B: Engineering, vol. 42, no. 5, pp. 1220-1225, 2011/07/01/ 2011, doi: https://doi.org/10.1016/j.compositesb.2011.02.011.

34. J. Andersons, E. Spārninš, and R. Joffe, "Stiffness and strength of flax fiber/polymer matrix composites," Polymer Composites, vol. 27, no. 2, pp. 221-229, 2006, doi: doi:10.1002/pc.20184.

35. A. Awal, M. Rana, and M. Sain, "Thermorheological and mechanical properties of cellulose reinforced PLA bio-composites," Mechanics of Materials, vol. 80, pp. 87-95, 2015/01/01/ 2015, doi: https://doi.org/10.1016/j.mechmat.2014.09.009.

36. V. Sadanand, N. Rajini, A. Varada Rajulu, and B. Satyanarayana, "Preparation of cellulose composites with in situ generated copper nanoparticles using leaf extract and their properties," Carbohydrate Polymers, vol. 150, pp. 32-39, 2016/10/05/ 2016, doi: https://doi.org/10.1016/j.carbpol.2016.04.121.

37. N. Bharath Kurki and S. Basavarajappa, "Applications of biocomposite materials based on natural fibers from renewable resources: a review," in Science and Engineering of Composite Materials vol. 23, ed, 2016, p. 123.

38. I. S. M. Tawakkal, R. A. Talib, K. Abdan, and C. N. Ling, "Mechanical and physical properties of kenaf-derived cellulose 
(KDC)-filled polylactic acid (PLA) composites," BioResources, vol. 7, no. 2, pp. 1643-1655, 2012.

39. R. A. Talib, I. S. M. A. Tawakkal, and A. Khalina, "The influence of mercerised kenaf fibres reinforced polylactic acid composites on dynamic mechanical analysis," in Key Engineering Materials, 2011, vol. 471: Trans Tech Publ, pp. 815-820.

40. D. Shumigin, E. Tarasova, A. Krumme, and P. Meier, "Rheological and mechanical properties of poly (lactic) acid/cellulose and LDPE/cellulose composites," Materials Science, vol. 17, no. 1, pp. 32-37, 2011.

41. H. Anuar, A. Zuraida, J. Kovacs, and T. Tabi, "Improvement of mechanical properties of injection-molded polylactic acid-kenaf fiber biocomposite," Journal of Thermoplastic Composite Materials, vol. 25 , no. 2 , pp. 153-164, 2012.

42. R. M. Taib, S. Ramarad, Z. A. M. Ishak, and M. Todo, "Properties of kenaf fiber/polylactic acid biocomposites plasticized with polyethylene glycol," Polymer composites, vol. 31, no. 7, pp. 1213$1222,2010$.

43. N. A. Ibrahim, W. M. Z. W. Yunus, M. Othman, K. Abdan, and K. A. Hadithon, "Poly (lactic acid)(PLA)-reinforced kenaf bast fiber composites: the effect of triacetin," Journal of reinforced plastics and composites, vol. 29, no. 7, pp. 1099-1111, 2010.

44. M. Fazeli, M. Keley, and E. Biazar, "Preparation and characterization of starch-based composite films reinforced by cellulose nanofibers," International Journal of Biological Macromolecules, vol. 116, pp. 272-280, 2018/09/01/ 2018, doi: https://doi.org/10.1016/j.ijbiomac.2018.04.186.

45. P. Mårtensson and Bcom. "powerRibs ${ }^{\mathrm{TM}}$ enables ocean plastic in automotive interior parts." http:/www.bcomp.ch/en/news/bcompenables-upcycling-of-ocean-plastic-for-automotive-interior-partsin-volvo-cars-recycled-plastics-demonstrator-vehicle (accessed 18/01/2019, 2019).

46. Kisspng. "Car Composite material Biocomposite Flax Fiberreinforced composite - flax hemp." https://www.kisspng.com/pngcar-composite-material-biocomposite-flax-fiber-rei-6578429/ (accessed 18/01/2019, 2019).

47. Christian Gahle. "Interior carpeting of a car's door made by a biocomposite of hemp fibres and polyethylene." https://en.wikipedia.org/wiki/Biocomposite\#/media/File:T\%C3\%B Crinnenverkleidung_Hanf-PP_nova.jpg (accessed 18/01/2019, 2019).

48. N. Composition. "Biocomposites at Composites Europe 2014." https://netcomposites.com/news/2014/july/1/biocomposites-atcomposites-europe-2014/ (accessed 18/01/2019, 2019).

49. A. Espert, F. Vilaplana, and S. Karlsson, "Comparison of water absorption in natural cellulosic fibres from wood and one-year crops in polypropylene composites and its influence on their mechanical properties," Composites Part A: Applied science and manufacturing, vol. 35, no. 11, pp. 1267-1276, 2004.

50. Y. Lei, Q. Wu, F. Yao, and Y. Xu, "Preparation and properties of recycled HDPE/natural fiber composites," Composites Part A: Applied Science and Manufacturing, vol. 38, no. 7, pp. 1664-1674, 2007/07/01/ 2007 , https://doi.org/10.1016/j.compositesa.2007.02.001.

51. H. Hamada, J. Denault, A. K. Mohanty, Y. Li, and M. S. Aly-Hassan, "Natural Fiber Composites," Advances in Mechanical Engineering, vol. 5, p. 569020, 2013/01/01 2013, doi: 10.1155/2013/569020.

52. P. J. Herrera-Franco and A. Valadez-González, "A study of the mechanical properties of short natural-fiber reinforced composites," Composites Part B: Engineering, vol. 36, no. 8, pp. 597-608, 2005/12/01/ 2005 , https://doi.org/10.1016/j.compositesb.2005.04.001.

53. M. Zampaloni et al., "Kenaf natural fiber reinforced polypropylene composites: A discussion on manufacturing problems and solutions," Composites Part A: Applied Science and Manufacturing, vol. 38, no. $6, \quad$ pp. 1569-1580, 2007/06/01/ 2007, doi: https://doi.org/10.1016/j.compositesa.2007.01.001.

54. V. K. Thakur, M. K. Thakur, and R. K. Gupta, "Review: Raw Natural Fiber-Based Polymer Composites," International Journal of Polymer Analysis and Characterization, vol. 19, no. 3, pp. 256-271, 2014/04/03 2014, doi: 10.1080/1023666X.2014.880016.

55. F. M. Al-Oqla and S. M. Sapuan, "Natural fiber reinforced polymer composites in industrial applications: feasibility of date palm fibers for sustainable automotive industry," Journal of Cleaner Production, vol. 66, pp. 347-354, 2014/03/01/ 2014, doi: https://doi.org/10.1016/j.jclepro.2013.10.050.

56. Y. Yang, R. Boom, B. Irion, D.-J. van Heerden, P. Kuiper, and H. de Wit, "Recycling of composite materials," Chemical Engineering and
Processing: Process Intensification, vol. 51, pp. 53-68, 2012/01/01/ 2012, doi: https://doi.org/10.1016/j.cep.2011.09.007.

57. J. Group. "The challenge of natural fibres in composite reinforcement."

http://www.jeccomposites.com/knowledge/internationalcomposites-news/challenge-natural-fibres-composite-reinforcement (accessed 12/06/2018, 2018).

58. S. N. Monteiro, F. P. D. Lopes, A. S. Ferreira, and D. C. O. Nascimento, "Natural-fiber polymer-matrix composites: Cheaper, tougher, and environmentally friendly," JOM, journal article vol. 61, no. 1, pp. 17-22, January 01 2009, doi: 10.1007/s11837-009-0004-z.

59. M. A. Meyers, P.-Y. Chen, A. Y.-M. Lin, and Y. Seki, "Biological materials: Structure and mechanical properties," Progress in Materials Science, vol. 53, no. 1, pp. 1-206, 2008/01/01/ 2008, doi: https://doi.org/10.1016/j.pmatsci.2007.05.002.

60. B. R. Reddy and S. H. Dhoria, "Effect of alkaline treatment on mechanical properties of kenaf fiber reinforced polyester composites," in AIP Conference Proceedings, 2018, vol. 1943, no. 1: AIP Publishing LLC, p. 020097.

61. K. Roy, S. C. Debnath, A. Das, G. Heinrich, and P. Potiyaraj, "Exploring the synergistic effect of short jute fiber and nanoclay on the mechanical, dynamic mechanical and thermal properties of natural rubber composites," Polymer Testing, vol. 67, pp. 487-493, 2018.

62. A. Kicińska-Jakubowska, E. Bogacz, and M. Zimniewska, "Review of Natural Fibers. Part I-Vegetable Fibers," Journal of Natural Fibers, vol. 9, no. 3, pp. 150-167, 2012/07/01 2012, doi: 10.1080/15440478.2012.703370.

63. S. Nwanonenyi, M. Obidiegwu, and G. Onuegbu, "Effects of particle sizes, filler contents and compatibilization on the properties of linear low density polyethylene filled periwinkle shell powder," International journal of Engineering and Science, vol. 2, no. 2, pp. 1-8, 2013.

64. S. Nwanonenyi, M. Obidiegwu, T. Onuchukwu, and I. Egbuna, "Studies on the properties of linear low density polyethylene filled oyster shell powder," The International Journal Of Engineering And Science, vol. 2, no. 7, p. 42, 2013.

65. N. Saba, M. P. Tahir, and M. Jawaid, "A Review on Potentiality of Nano Filler/Natural Fiber Filled Polymer Hybrid Composites," Polymers, vol. 6, no. 8, 2014, doi: 10.3390/polym6082247.

66. V. Paul, "Synthesis and characterization of a biocomposite derived from banana plants (Musa cavendish)," 2015.

67. R. Singh, R. Gupta, M. G. Adsul, R. C. Kuhad, D. V. Gokhale, and A. J. Varma, "Biodegradation of Styrene-Butadiene-Styrene Coploymer via Sugars Attached to the Polymer Chain," Advances in Materials Physics and Chemistry, vol. 3, no. 02, p. 112, 2013.

68. S. Elanthikkal, U. Gopalakrishnapanicker, S. Varghese, and J. T. Guthrie, "Cellulose microfibres produced from banana plant wastes: Isolation and characterization," Carbohydrate Polymers, vol. 80, no. 3, pp. 852-859, 2010.

69. "Lignin," in Kirk-Othmer Encyclopedia of Chemical Technology.

70. N. D. Patil, N. R. Tanguy, and N. Yan, "3 - Lignin Interunit Linkages and Model Compounds," in Lignin in Polymer Composites, O. Faruk and M. Sain Eds.: William Andrew Publishing, 2016, pp. 27-47.

71. V. Paul, "SYNTHESIS AND CHARACTERIZATION OF A BIOCOMPOSITE DERIVED FROM BANANA PLANTS (MUSA CAVENDISH)," Doctor of Philosophy Chemical Durban University of Technology 2015.

72. Wikipedia.

"Lignin." https://en.wikipedia.org/wiki/Lignin\#cite_note-2 (accessed 2019).

73. S. K. Ramamoorthy, M. Skrifvars, and A. Persson, "A Review of Natural Fibers Used in Biocomposites: Plant, Animal and Regenerated Cellulose Fibers," Polymer Reviews, vol. 55, no. 1, pp. 107-162, 2015/01/02 2015, doi: 10.1080/15583724.2014.971124.

74. A. J. Ragauskas et al., "Lignin Valorization: Improving Lignin Processing in the Biorefinery," Science, vol. 344, no. 6185, p. 1246843, 2014, doi: 10.1126/science.1246843.

75. A. Valadez-González and P. J. H. Franco, "Fiber-Matrix Adhesion in Natural Fiber Composites," in Natural Fibers, Biopolymers, and Biocomposites: CRC Press, 2005, pp. 196-252.

76. P. Bataille, N. Belgacem, and S. Sapieha, "Properties of cellulosepolypropylene composites subjected to corona treatment," in Proc. SPE ANTEC, 1993, vol. 39, pp. 325-329.

77. H. L. Richards, P. G. Baker, and E. Iwuoha, "Metal nanoparticle modified polysulfone membranes for use in wastewater treatment: a critical review," Journal of Surface Engineered Materials and Advanced Technology, vol. 2, no. 03, p. 183, 2012.

78. D. Klemm, B. Heublein, H.-P. Fink, and A. Bohn, "Cellulose: Fascinating Biopolymer and Sustainable Raw Material," 
Angewandte Chemie International Edition, vol. 44, no. 22, pp. 33583393, 2005, doi: doi:10.1002/anie.200460587.

79. M.-p. Ho et al., "Critical factors on manufacturing processes of natural fibre composites," Composites Part B: Engineering, vol. 43 , no. $8, \quad$ pp. 3549-3562, 2012/12/01/ 2012, doi: https://doi.org/10.1016/j.compositesb.2011.10.001.

80. K. L. Pickering, M. G. A. Efendy, and T. M. Le, "A review of recent developments in natural fibre composites and their mechanical performance," Composites Part A: Applied Science and Manufacturing, vol. 83, pp. 98-112, 2016/04/01/ 2016, doi: https://doi.org/10.1016/j.compositesa.2015.08.038.

81. BananaLinks. "All About Banana." https://www.bananalink.org.uk/all-about-bananas/ (accessed 01/27, 2020).

82. A. G. Temesgen and O. Sahu, "Process ability enhancement of false banana fibre for rural development," Cellulose, vol. 67, no. 67.89, p. 67.63, 2014.

83. L. A. Pothan, Z. Oommen, and S. Thomas, "Dynamic mechanical analysis of banana fiber reinforced polyester composites," Composites Science and technology, vol. 63, no. 2, pp. 283-293, 2003.

84. N. Venkateshwaran and A. Elayaperumal, "Banana fiber reinforced polymer composites-a review," Journal of Reinforced Plastics and Composites, vol. 29, no. 15, pp. 2387-2396, 2010.

85. M. Boopalan, M. Niranjanaa, and M. Umapathy, "Study on the mechanical properties and thermal properties of jute and banana fiber reinforced epoxy hybrid composites," Composites Part B: Engineering, vol. 51, pp. 54-57, 2013.

86. H. Dhakal, Z. Zhang, and M. Richardson, "Effect of water absorption on the mechanical properties of hemp fibre reinforced unsaturated polyester composites," Composites science and technology, vol. 67, no. 7-8, pp. 1674-1683, 2007.

87. P. Wambua, J. Ivens, and I. Verpoest, "Natural fibres: can they replace glass in fibre reinforced plastics?," Composites science and technology, vol. 63, no. 9, pp. 1259-1264, 2003.

88. C. Deo and S. Acharya, "Effect of moisture absorption on mechanical properties of chopped natural fiber reinforced epoxy composite," Journal of reinforced plastics and composites, vol. 29, no. 16, pp. 2513-2521, 2010

89. L. Yan, N. Chouw, and X. Yuan, "Improving the mechanical properties of natural fibre fabric reinforced epoxy composites by alkali treatment," Journal of Reinforced Plastics and Composites, vol. 31, no. 6, pp. 425-437, 2012.

90. H. Anuar and A. Zuraida, "Improvement in mechanical properties of reinforced thermoplastic elastomer composite with kenaf bast fibre," Composites Part B: Engineering, vol. 42, no. 3, pp. 462-465, 2011.

91. P. Herrera-Franco and A. Valadez-Gonzalez, "A study of the mechanical properties of short natural-fiber reinforced composites," Composites Part B: Engineering, vol. 36, no. 8, pp. 597-608, 2005.

92. Y. Cao, S. Shibata, and I. Fukumoto, "Mechanical properties of biodegradable composites reinforced with bagasse fibre before and after alkali treatments," Composites part A: Applied science and Manufacturing, vol. 37, no. 3, pp. 423-429, 2006.

93. I. Van de Weyenberg, T. C. Truong, B. Vangrimde, and I. Verpoest, "Improving the properties of UD flax fibre reinforced composites by applying an alkaline fibre treatment," Composites Part A: Applied Science and Manufacturing, vol. 37, no. 9, pp. 1368-1376, 2006.

94. K. Anbukarasi and S. Kalaiselvam, "Study of effect of fibre volume and dimension on mechanical, thermal, and water absorption behaviour of luffa reinforced epoxy composites," Materials \& Design (1980-2015), vol. 66, pp. 321-330, 2015/02/05/ 2015, doi: https://doi.org/10.1016/j.matdes.2014.10.078.

95. X. Li, L. G. Tabil, and S. Panigrahi, "Chemical treatments of natural fiber for use in natural fiber-reinforced composites: a review," Journal of Polymers and the Environment, vol. 15, no. 1, pp. 25-33, 2007.

96. K. Goda, M. Sreekala, A. Gomes, T. Kaji, and J. Ohgi, "Improvement of plant based natural fibers for toughening green composites-Effect of load application during mercerization of ramie fibers," Composites Part A: Applied science and manufacturing, vol. 37, no. 12, pp. 2213-2220, 2006.

97. M. S. Meon, M. F. Othman, H. Husain, M. F. Remeli, and M. S. M. Syawal, "Improving Tensile Properties of Kenaf Fibers Treated with Sodium Hydroxide," Procedia Engineering, vol. 41, pp. 1587-1592, 2012/01/01/ 2012 , https://doi.org/10.1016/j.proeng.2012.07.354

98. A. M. M. Edeerozey, H. M. Akil, A. B. Azhar, and M. I. Z. Ariffin, "Chemical modification of kenaf fibers," Materials Letters, vol. 61, no. $10, \quad p p .2023-2025$ https://doi.org/10.1016/j.matlet.2006.08.006.

99. Q. Viel, "Interface properties of bio-based composites of polylactic acid and bamboo fibers," 2013

100.R. Vinayagamoorthy, "Influence of fiber surface modifications on the mechanical behavior of Vetiveria zizanioides reinforced polymer composites," Journal of Natural Fibers, pp. 1-12, 2017.

101.A. Abdal-Hay, N. P. G. Suardana, K.-S. Choi, and J. K. Lim, "Effect of diameters and alkali treatment on the tensile properties of date palm fiber reinforced epoxy composites," International Journal of Precision Engineering and Manufacturing, vol. 13, no. 7, pp. 11991206, 2012.

102.H. Suryanto, E. Marsyahyo, Y. S. Irawan, and R. Soenoko, "Morphology, structure, and mechanical properties of natural cellulose fiber from mendong grass (Fimbristylis globulosa)," Journal of Natural Fibers, vol. 11, no. 4, pp. 333-351, 2014.

103.N. A. Ibrahim, W. M. Z. W. Yunus, M. Othman, and K. Abdan, "Effect of chemical surface treatment on the mechanical properties of reinforced plasticized poly (lactic acid) biodegradable composites," Journal of Reinforced Plastics and Composites, vol. 30, no. 5, pp. 381-388, 2011.

104.R. Vinayagamoorthy, "Parametric optimization studies on drilling of sandwich composites using the Box-Behnken design," Materials and Manufacturing Processes, vol. 32, no. 6, pp. 645-653, 2017.

105.A. Sunija, S. S. Ilango, and K. Vinod Kumar, "Thespesia populnea reinforced cashew nut husk tannin-based polyurethane composites," Journal of natural fibers, vol. 12, no. 5, pp. 481-493, 2015.

106.E. T. N. Bisanda and M. P. Ansell, "The effect of silane treatment on the mechanical and physical properties of sisal-epoxy composites," Composites Science and Technology, vol. 41, no. 2, pp. 165-178, 1991/01/01/ 1991, doi: https://doi.org/10.1016/02663538(91)90026-L.

107.M. M.-U. Haque, M. Maniruzzaman, and M. S. Reza, "Thermal and tensile mechanical behavior of polystyrene graft acetic anhydridetreated pulque fibers," Journal of natural fibers, vol. 13, no. 2, pp. $125-136,2016$

108. M. Misnon, M. Islam, J. Epaarachchi, and K. Lau, "Textile material forms for reinforcement materials: a review," in Proceedings of the 3rd Malaysian Postgraduate Conference (MPC 2013), 2013 Education Malaysia, pp. 105-123.

109.A. e. Mustafa, M. F. B. Abdollah, F. F. Shuhimi, N. Ismail, H Amiruddin, and N. Umehara, "Selection and verification of kenaf fibres as an alternative friction material using Weighted Decision Matrix method," Materials \& Design, vol. 67, pp. 577-582, 2015/02/15/ 2015 , https://doi.org/10.1016/j.matdes.2014.10.091.

110.T. M. Le and K. L. Pickering, "The potential of harakeke fibre as reinforcement in polymer matrix composites including modelling of long harakeke fibre composite strength," Composites Part A: Applied Science and Manufacturing, vol. 76, pp. 44-53, 2015.

111.F. Namvar et al., "Potential use of plant fibres and their composites for biomedical applications," BioResources, vol. 9, no. 3, pp. 5688 5706,2014

112.I. Aji, S. Sapuan, E. Zainudin, and K. Abdan, "Kenaf fibres as reinforcement for polymeric composites: a review," International Journal of Mechanical and Materials Engineering, vol. 4, no. 3, pp. 239-248, 2009.

113.Z. Liang, P. Pan, B. Zhu, T. Dong, and Y. Inoue, "Mechanical and thermal properties of poly(butylene succinate)/plant fiber biodegradable composite," Journal of Applied Polymer Science, vol. 115, no. 6, pp. 3559-3567, 2010, doi: 10.1002/app.29848.

114.S. Shibata, Y. Cao, and I. Fukumoto, "Lightweight laminate composites made from kenaf and polypropylene fibres," Polymer Testing, vol. 25, no. 2, pp. 142-148, 2006.

115.J. Szalay. "Bananas: Health Benefits, Risks \& Nutrition Facts." Live Science Contributor. https://www.livescience.com/45005-banananutrition-facts.html (accessed 2020/01/28, 2020).

116.BananaLinks. "All About Bananas." https://www.bananalink.org.uk/all-about-bananas/_ (accessed 2020/02/28, 2020)

117.A. B. Guerrero, P. L. Aguado, J. Sánchez, and M. D. Curt, "GISBased Assessment of Banana Residual Biomass Potential for Ethanol Production and Power Generation: A Case Study," Waste and Biomass Valorization, vol. 7, no. 2, pp. 405-415, 2016/04/01 2016, doi: 10.1007/s12649-015-9455-3.

118.f. f. Department of Agriculture. "PROFILE OF THE SOUTH AFRICAN BANANA MARKET VALUE CHAIN." https://www.nda.agric.za/doaDev/sideMenu/Marketing/Annual\%20 Publications/Commodity\%20Profiles/FRUITS\%20AND\%20VEGE 
Gbadeyan Oluwatoyin Joseph, Sarp Adali, Glen Bright and Bruce Sithole/

Journal of Engineering Science and Technology Review 14 (5) (2021) 61 - 74

TABLES/Banana\%20market\%20value\%20chain\%20profile\%2020 15.pdf (accessed 30/01/2020, 2020).

119.M. Intelligence. "Banana Market Size, Share, Analysis - Growth, Trends, and Forecast (2020 - 2025)." https://www.mordorintelligence.com/industry-reports/bananamarket (accessed 2020/01/28

120.L. Oliveira, N. Cordeiro, D. Evtuguin, I. Torres, and A. Silvestre, "Chemical composition of different morphological parts from 'Dwarf Cavendish'banana plant and their potential as a non-wood renewable source of natural products," Industrial Crops and Products, vol. 26, no. 2, pp. 163-172, 2007.

121.K. Li, S. Fu, H. Zhan, Y. Zhan, and L. Lucia, "Analysis of the chemical composition and morphological structure of banana pseudo-stem," BioResources, vol. 5, no. 2, pp. 576-585, 2010.

122.P. Ganán, R. Zuluaga, J. M. Velez, and I. Mondragon, "Biological natural retting for determining the hierarchical structuration of banana fibers," Macromolecular bioscience, vol. 4, no. 10, pp. 978983, 2004.

123.K. Ebisike, B. AttahDaniel, B. Babatope, and S. Olusunle, "Studies on the extraction of naturally-occurring banana fibers," Int J Eng Sci, vol. 2 , no. 9 , p. 9,2013

124.I. Sarma and A. Deka, "Banana fibre extraction by mycogenic pectinase enzyme (S)-an eco-friendly approach," Imperial Journal of Interdisciplinary Research, vol. 2, no. 10, pp. 997-1006, 2016.

125.K. P. Kumar and A. S. J. Sekaran, "Some natural fibers used in polymer composites and their extraction processes: A review," Journal of Reinforced Plastics and Composites, vol. 33, no. 20, pp. 1879-1892, 2014.

126.W. Fiber. "Uses of Abaca." http://www.wigglesworthfibres.com/products/abaca/abacaplant.htm 1 (accessed 2020/01/30, 2020).

127.T. school. "Banana Fibers- Natural plant/ Bast Fiber." https://www.textileschool.com/131/banana-fibers-natural-plantbast-fibers/ (accessed 2020/01/30.

128.L. A. Pothan, S. Thomas, and N. Neelakantan, "Short banana fiber reinforced polyester composites: mechanical, failure and aging characteristics," Journal of Reinforced Plastics and Composites, vol. 16, no. 8, pp. 744-765, 1997.

129.M. Maleque, F. Belal, and S. Sapuan, "Mechanical properties study of pseudo-stem banana fiber reinforced epoxy composite," The Arabian journal for science and engineering, vol. 32, no. 2B, pp. 359-364, 2007.

130.T. Mohan and K. Kanny, "Nanoclay infused banana fiber and its effects on mechanical and thermal properties of composites," Journal of Composite Materials, vol. 50, no. 9, pp. 1261-1276, 2016, doi: $10.1177 / 0021998315590265$.

131.S. Joseph and S. Thomas, "Electrical properties of banana fiberreinforced phenol formaldehyde composites," Journal of Applied Polymer Science, vol. 109, no. 1, pp. 256-263, 2008, doi: 10.1002/app. 27452.

132.M. Ramesh, T. S. A. Atreya, U. Aswin, H. Eashwar, and C. Deepa, "Processing and mechanical property evaluation of banana fiber reinforced polymer composites," Procedia Engineering, vol. 97, pp. 563-572, 2014

133.M. Boopalan, M. Niranjanaa, and M. J. Umapathy, "Study on the mechanical properties and thermal properties of jute and banana fiber reinforced epoxy hybrid composites," Composites Part B: Engineering, vol. 51, pp. 54-57, 2013/08/01/ 2013, doi: https://doi.org/10.1016/j.compositesb.2013.02.033.

134.L. A. Pothan, S. Thomas, and N. R. Neelakantan, "Short Banana Fiber Reinforced Polyester Composites: Mechanical, Failure and Aging Characteristics," Journal of Reinforced Plastics and Composites, vol. 16, no. 8, pp. 744-765, 1997, doi: $10.1177 / 073168449701600806$

135.K. Iqbal, S.-U. Khan, A. Munir, and J.-K. Kim, "Impact damage resistance of CFRP with nanoclay-filled epoxy matrix," Composites Science and Technology, vol. 69, no. 11-12, pp. 1949-1957, 2009.

136.A. Nourbakhsh, F. F. Baghlani, and A. Ashori, "Nano-SiO2 filled rice husk/polypropylene composites: Physico-mechanical properties," Industrial Crops and Products, vol. 33, no. 1, pp. 183187, 2011/01/01/ 2011, doi https://doi.org/10.1016/j.indcrop.2010.10.010.

137.A. Meera, S. Said, Y. Grohens, A. Luyt, and S. Thomas, "Tensile stress relaxation studies of $\mathrm{TiO} 2$ and nanosilica filled natural rubber composites," Industrial \& engineering chemistry research, vol. 48, no. 7, pp. 3410-3416, 2009.

138. Toledano-Maga et al., "Effect of Clinoptilolite and Sepiolite Nanoclays on Human and Parasitic Highly Phagocytic Cells,"
BioMed Research International, vol. 2015, p. 12, 2015, Art no. 164980, doi: $10.1155 / 2015 / 164980$.

139.B. Wen et al., "Temperature dependent microwave attenuation behavior for carbon-nanotube/silica composites," Carbon, vol. 65, pp. 124-139, 2013/12/01/ 2013, doi: https://doi.org/10.1016/j.carbon.2013.07.110.

140.O. J. Gbadeyan, "Low friction hybrid nanocomposite material for brake pad application," 2017.

141.M. R. Sanjay, P. Madhu, M. Jawaid, P. Senthamaraikannan, S Senthil, and S. Pradeep, "Characterization and properties of natural fiber polymer composites: A comprehensive review," Journal of Cleaner Production, vol. 172, pp. 566-581, 2018/01/20/ 2018, doi: https://doi.org/10.1016/j.jclepro.2017.10.101.

142.P. Vijayan P, D. Puglia, M. A. S. A. Al-Maadeed, J. M. Kenny, and S. Thomas, "Elastomer/thermoplastic modified epoxy nanocomposites: The hybrid effect of 'micro' and 'nano' scale," Materials Science and Engineering: R: Reports, vol. 116, pp. 1-29, 2017/06/01/ 2017, doi: https://doi.org/10.1016/j.mser.2017.03.001.

143.G. C. Onuegbu and I. O. Igwe, "The effects of filler contents and particle sizes on the mechanical and end-use properties of snail shell powder filled polypropylene," Materials Sciences and Applications, vol. 2, no. 07, p. 810, 2011.

144.P. Deogonda and V. N. Chalwa, "Mechanical property of glass fiber reinforcement epoxy composites," International Journal of Scientific Engineering and Research (IJSER), vol. 1, no. 4, pp. 2347-3878, 2013.

145.C. M. Müller, J. B. Laurindo, and F. Yamashita, "Composites of thermoplastic starch and nanoclays produced by extrusion and thermopressing," Carbohydrate polymers, vol. 89, no. 2, pp. 504510, 2012.

146.S. M. Dizaj, M. Barzegar-Jalali, M. H. Zarrintan, K. Adibkia, and F. Lotfipour, "Calcium carbonate nanoparticles; potential in bone and tooth disorders," Pharmaceutical Sciences, vol. 20, no. 4, p. 175, 2015.

147.M. Balachandran, S. Devanathan, R. Muraleekrishnan, and S. Bhagawan, "Optimizing properties of nanoclay-nitrile rubber (NBR) composites using face centred central composite design," Materials \& Design, vol. 35, pp. 854-862, 2012

148.M. Balachandran and S. Bhagawan, "Mechanical, thermal and transport properties of nitrile rubber (NBR) - nanoclay composites," Journal of Polymer Research, vol. 19, no. 2, p. 9809, 2012.

149.P. Reis, J. Ferreira, P. Santos, M. Richardson, and J. Santos, "Impact response of Kevlar composites with filled epoxy matrix," Composite Structures, vol. 94, no. 12, pp. 3520-3528, 2012.

150.L. Marrot, A. Bourmaud, P. Bono, and C. Baley, "Multi-scale study of the adhesion between flax fibers and biobased thermoset matrices," Materials \& Design (1980-2015), vol. 62, pp. 47-56, 2014/10/01/ 2014 , https://doi.org/10.1016/j.matdes.2014.04.087.

151.S. C. Onwubu, A. Vahed, S. Singh, and K. M. Kanny, "Physicochemical characterization of a dental eggshell powder abrasive material," (in eng), Journal of applied biomaterials \& functional materials, vol. 15, no. 4, pp. e341-e346, Nov 10 2017, doi: $10.5301 / \mathrm{jabfm} .5000361$.

152.M. T. Hincke, Y. Nys, J. Gautron, K. Mann, A. B. RodriguezNavarro, and M. D. McKee, "The eggshell: structure, composition and mineralization," Front Biosci, vol. 17, no. 1266, p. 120, 2012.

153.S. Patrick, V. Aigbodion, and S. Hassan, "Development of polyester/eggshell particulate composites," Tribology in industry, vol. 34, no. 4, pp. 217-225, 2012.

154.J. R. Woodard et al., "The mechanical properties and osteoconductivity of hydroxyapatite bone scaffolds with multi-scale porosity," Biomaterials, vol. 28, no. 1, pp. 45-54, 2007/01/01/ 2007, doi: https://doi.org/10.1016/j.biomaterials.2006.08.021.

155.I. O. Igwe, A. A. J. M. S. Ejim, and Applications, "Studies on mechanical and end-use properties of natural rubber filled with snail shell powder," vol. 2, no. 07, p. 801, 2011.

156.F. Senatov, D. Kuznetsov, S. Kaloshkin, and V. Cherdyntsev, "Obtaining Nanopowders of Metal Oxides from Salts by Means of Mechanochemical Synthesis," CHEMISTRY FOR SUSTAINABLE DEVELOPMENT, vol. 17, no. 6, pp. 631-636, 2009.

157.T. K. Achar, A. Bose, and P. Mal, "Mechanochemical synthesis of small organic molecules," Beilstein journal of organic chemistry, vol. 13, no. 1, pp. 1907-1931, 2017

158.F. H. Tobins, O. Abubakre, R. Muriana, and S. Abdulrahman, "Snail Shell as an Inspiring Engineering Material in Science and Technology Development: A Review," International Journal of Contemporary Research and Review, vol. 9, no. 03, pp. 2040820416, 2018 
Gbadeyan Oluwatoyin Joseph, Sarp Adali, Glen Bright and Bruce Sithole/

Journal of Engineering Science and Technology Review 14 (5) (2021) 61 - 74

159.M. Kolawole, a. Aweda, and S. Abdulkareem, "Archachatina marginata bio-shells as reinforcement material in metal matrix composites," International Journal of Automotive \& Mechanical Engineering, vol. 14, no. 1, 2017.

160.M. Barros, P. Bello, M. Bao, and J. Torrado, "From waste to commodity: transforming shells into high purity calcium carbonate," Journal of Cleaner Production, vol. 17, no. 3, pp. 400-407, 2009.

161.U. Onyes. "COMPLETE GUIDE TO SNAIL REAING IN NIGERIA."

https://www.academia.edu/34462065/COMPLETE_GUIDE_TO_S NAIL REAING IN NIGERIA (accessed 19/03/2019, 2019).

162.G. Uys, "Snail farming: making good use of a small space," vol. 2019, ed, 2017.

163.A. Powell, "Western Cape's snail farm to yield R28,5m," ed: IOL, 2007.

164.S. G. Tan and W. S. Chow, "Biobased Epoxidized Vegetable Oils and Its Greener Epoxy Blends: A Review," Polymer-Plastics
Technology and Engineering, vol. 49, no. 15, pp. 1581-1590, 2010/11/22 2010, doi: 10.1080/03602559.2010.512338.

165.T. Iwata, "Biodegradable and Bio-Based Polymers: Future Prospects of Eco-Friendly Plastics," Angewandte Chemie International Edition, vol. 54, no. 11, pp. 3210-3215, 2015, doi: 10.1002/anie.201410770.

166.B. Lin, L. Yang, H. Dai, and A. Yi, "Kinetic studies on oxirane cleavage of epoxidized soybean oil by methanol and characterization of polyols," Journal of the American Oil Chemists' Society, vol. 85, no. 2, pp. 113-117, 2008.

167.H. Miyagawa, R. J. Jurek, A. K. Mohanty, M. Misra, and L. T. Drzal, "Biobased epoxy/clay nanocomposites as a new matrix for CFRP," Composites Part A: Applied Science and Manufacturing, vol. 37, no. 1, pp. 54-62, 2006/01/01/ 2006, doi: https://doi.org/10.1016/j.compositesa.2005.05.014. 